\title{
Elaboration and Quality of Greek Yogurt (labneh) from Buffalo Milk Supplemented with Plus açaí jelly (Euterpe oleracea Mart.)
}

\author{
Wagner Barreto da Silva \\ Escola de Ensino Técnico do Estado do Pará - EETEPA, Brazil \\ Vanessa Vieira Lourenço-Costa \\ Universidade Federal do Pará- UFPA/Faculdade de Nutrição, Brazil
}

Higo Otávio Brochado Campos, Wânia Mendonça dos Santos, Andréia Santana Bezerra Universidade Federal do Pará - UFPA, Brazil

Jamile Andréa Rodrigues da Silva

Universidade Federal Rural da Amazônia - UFRA, Brazil

José de Brito Lourenço-Júnior

Programa de Pós-graduação em Ciência Animal - UFPA-Embrapa-UFRA, Brazil

Received: December 14, 2020

Accepted: January 6, 2021 Published: January 13, 2021

doi:10.5296/jas.v9i1.18059

URL: https://doi.org/10.5296/jas.v9i1.18059

\begin{abstract}
Buffalo milk has a high nutritional value, with high fat, protein, and mineral levels. Its derivatives yield exceeds by $40 \%$ those derived from bovine milk. As a way to take advantage of this quality, Greek yogurt (Labneh) is an alternative to add value to this important product. Thus, this work aims to prepare Greek yogurt with buffalo milk, added with açaí jelly (Euterpe oleracea Mart.), to carry out physical-chemical, microbiological, sensory, and texture profile analyzes in buffalo milk, Greek yogurt, and in açaí jelly. Natural Greek yogurt had an acceptability index of $90.11 \%$ and Greek yogurt with açaí jelly, $93.11 \%$,
\end{abstract}


which constitutes an alternative for regional raw material valorization, with excellent acceptability, high nutritional value, and outstanding physical-chemical and microbiological quality. Thus, this derivative is indicated for special programs supported by the City Halls and/or Government of Pará state, as a way of generating income and employment for communities producing buffalo milk and açaí.

Keywords: adding value, school feeding, Amazonian fruit, technological innovation

\section{Introduction}

Bubalinoculture in Brazil stands out for being an attractive market for the buffalo milk products segment. Interest in the use of this milk in cheese production in Pará state has increased considerably over the past few years (Bittencourt et al., 2013). Buffalo milk has high nutritional value, high levels of fat, proteins, and minerals, which is the greatest advantage over milk of other species. It has an average fat content of $6.3 \%$ (Soares et al., 2013 ) and surpasses cattle by around $4 \%$, positively influencing derivatives' production.

Due to the demand for alternative, healthy foods with nutraceutical or functional characteristics (with medicinal properties), buffalo milk comes as an option for presenting nutritional values superior to bovine milk (Verruma and Salgado, 1994). As a way of enjoying buffalo milk quality, Greek yogurt (labneh) is an alternative to add value to this important product. It is considered a derivative between traditional fermented milk and unripened cheeses, with high moisture content (Silveira et al., 2016), and among those with the highest production and consumption in the world (Senel et al., 2011).

To diversify and innovate the taste of Greek yogurt, açaí (Euterpe oleraceae Martius) can be used, a typical Amazonian fruit, which has peculiar and interesting characteristics for consumers and is widely available in the region. The açaí pulp has several antioxidants, such as anthocyanins (Darnet et al., 2011; Gouvea et al., 2012; Lima et al., 2012), considered anticarcinogenic, anti-inflammatory, antimicrobial, prevent LDL oxidation, and cardiovascular and neurological diseases (Oliveira et al., 2010; Bonomo et al., 2014).

Through meals, it is possible to insert foods that bring health benefits. Brazil follows school feeding guidelines through the National School Feeding Program (PNAE), which has the purpose of meeting students' nutritional needs, while in school (Brasil, 2006). Therefore, there is a need to encourage the participation of animal products in school meals; in this case, Greek yogurt, made with buffalo milk, aiming at rural development, with the opening of the market for local producers. Thus, this research aims to generate technological innovations, through the elaboration of Greek yogurt, from buffalo milk, added with açaí jelly, with high physical-chemical, microbiological and sensory qualities, and with possibilities of including it in school meals of municipal and state public networks.

\section{Material and Methods}

\subsection{Preliminary Tests}

In a preliminary test, natural Greek yogurt (NGY) was made with buffalo milk, using treatments with different milk cream amounts, between $0 \%$ and $20 \%$. Milk cream amount also 
influenced yogurt consistency, so the percentages of each component are shown in Table 1.

Table 1. Percentage of treatments' components for Natural Greek Yogurt

\begin{tabular}{lccccc}
\hline \multirow{2}{*}{ Component } & $\mathrm{T}_{1}$ & $\mathrm{~T}_{2}$ & $\mathrm{~T}_{3}$ & $\mathrm{~T}_{4}$ & $\mathrm{~T}_{5}$ \\
\cline { 2 - 6 } & \multicolumn{5}{c}{$\%$} \\
\hline Sucrose & 8 & 8 & 8 & 8 & 8 \\
Milk cream & 0 & 5 & 10 & 15 & 20 \\
Whole milk powder & 10 & 10 & 10 & 10 & 10 \\
Modified starch & 1 & 1 & 1 & 1 & 1 \\
Potassium sorbate & 0.03 & 0.03 & 0.03 & 0.03 & 0.03 \\
\hline
\end{tabular}

Sensory evaluation was performed, through the hedonic scale, on attributes: aroma, color, odor, texture, and global acceptance, with 60 voluntary judges, among students and civil servants of the Pará State University (Universidade do Estado do Pará - UEPA), untrained and of both genders. After the Tukey test $(\mathrm{p} \leq 0.05)$, the most accepted treatment was chosen to be developed.

\subsection{Greek Yogurt Preparation With Açaí Jelly}

The skimmed buffalo milk received heat treatment, in aluminum pans, at a temperature of 95 ${ }^{\circ} \mathrm{C}$, for 5 minutes, to destroy pathogenic microorganisms and other thermo-resistants. Then, $10 \%(\mathrm{w} / \mathrm{v})$ of whole milk powder was added to increase the consistency and yield of Greek yogurt, and $4 \%(\mathrm{w} / \mathrm{v})$ of sucrose, to have enough carbohydrate in the fermentation of sugars by microorganisms. Subsequently, it was cooled to $\pm 43^{\circ} \mathrm{C}$, in an 'ice bath', and $0.6 \%(\mathrm{w} / \mathrm{v})$ of lyophilized culture, composed of Lactobacillus acidophilus, Bifidobacterium and Streptococcus thermophilus, was inoculated, fermenting at $43{ }^{\circ} \mathrm{C}$, in an oven of air circulation, until reaching the $\mathrm{pH}$ of 4.6 to 4.8 .

NGY and açaí jelly production are illustrated in Figure 1. NGY (1A); açaí pulp jelly (1B). 
1A. Natural Greek yogurt

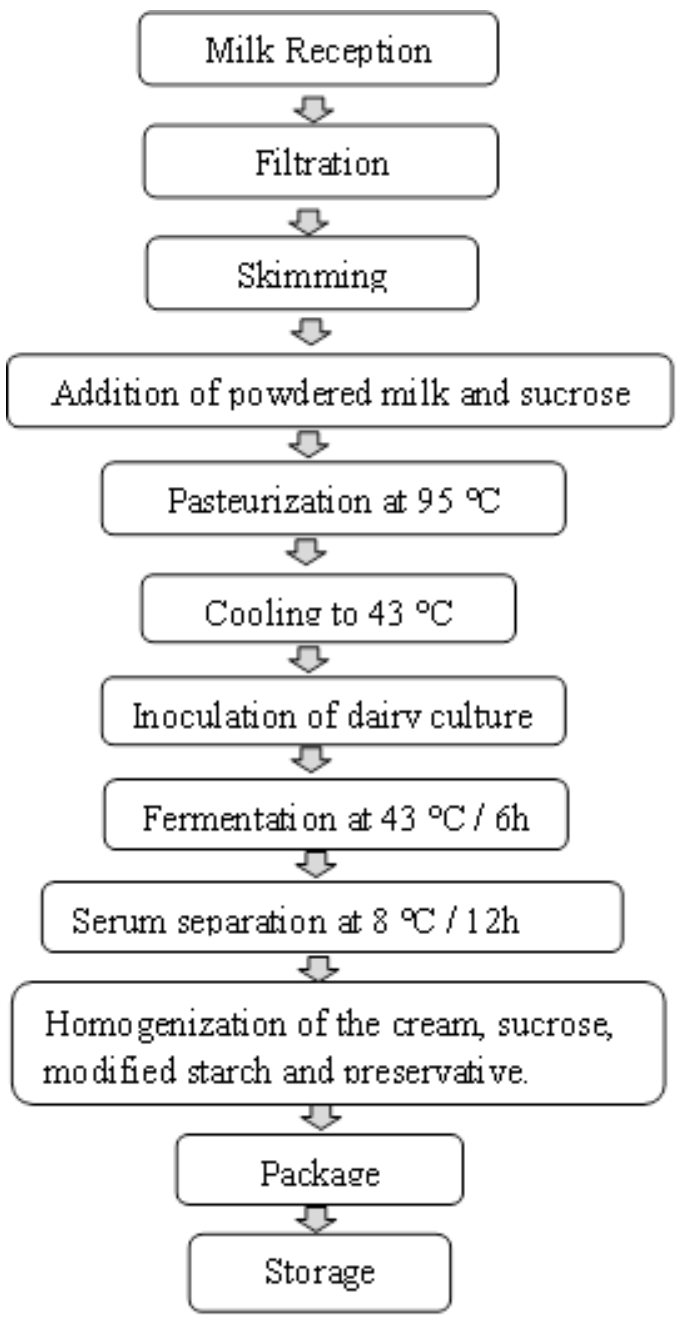

1B. Açaí pulp jelly

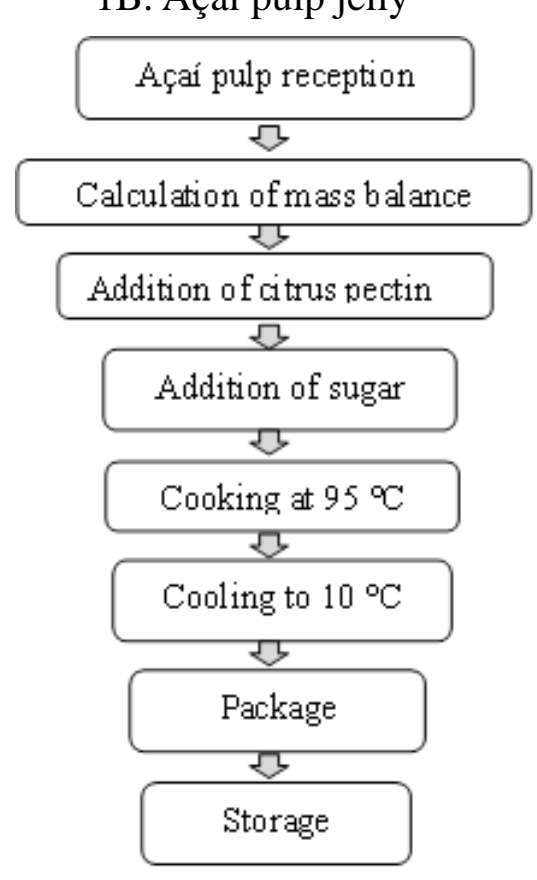

Figure 1. Flowchart for preparing natural Greek yogurt with buffalo milk and açaí pulp jelly

With the end milk fermentation, the curd was broken, deposited in cotton fabric, previously sanitized and sterilized, trapped in a properly closed plastic container; then stored at $8{ }^{\circ} \mathrm{C}$, and drained for 12 hours. $10 \%$ sour cream, 4\% sucrose, $1 \%$ modified starch, and $0.03 \%$ conservative potassium sorbate were added to the curd, which was homogenized. Açaí jelly was made with $46.9 \%$ fruit pulp at $8{ }^{\circ}$ Brix, $51.6 \%$ sucrose, and $1.5 \%$ pectin, prepared in a stainless steel pan, where it remained under constant heating and movement until reaches 60 ${ }^{\circ}$ Brix. Subsequently, it was cooled to complete the açaí jelly gelation.

\subsection{Laboratory Analysis}

Physical and chemical characterizations of buffalo milk, NGY, and açaí jelly (AJ) were carried out. And from açaí jelly, for titratable acidity, hydrogen potential $(\mathrm{pH})$, humidity, fixed mineral residue (ash), crude protein, and soluble solids, according to the Analytical Standards of the Instituto Adolfo Lutz (1985) - Instituto Adolfo Lutz. Total lipids Bligh-Dyer (Bligh and Dyer, 1959), and total carbohydrates were according to Resolution RDC No. 360, December 23, 2003 (Brazil, 2003). Energy value through the Atwater factors, 4 - 9 - $4 \mathrm{kcal} / \mathrm{g}$, respectively, for proteins, lipids, and total carbohydrates, according to 
resolution RDC No.360, December 23, 2003 (Brasil, 2003).

NGY was analyzed in an indicative way, for coliforms at $45^{\circ} \mathrm{C}$ and Salmonella sp, with results compared to tolerance parameters required by RDC No. 12, January 2, 2001 (Anvisa, 2001), for raw milk, pasteurized milk, NGY, and the jelly. Salmonella sp identification was made for raw milk, pasteurized milk, and NGY. For NGY and açaí jelly was made filamentous fungi and yeasts identification. All analyses were made according to the methodology of Silva et al. (2001).

Texture profile variables were analyzed for fracturing, hardness, cohesiveness, adhesiveness, elasticity, gumminess, and chewability. In a TA-XT2 texturometer, samples were analyzed under a temperature of $8{ }^{\circ} \mathrm{C}$ and the compression was performed with speed in the pre-test at $2.0 \mathrm{~mm} / \mathrm{s}$ and $2.0 \mathrm{~mm} / \mathrm{s}$, with a contact time of five seconds and contact force of $1 \mathrm{~g}$ (Van Dender et al., 2005). The analyzes were carried out in four replicates, at the Brazilian Agricultural Research Corporation - Embrapa Amazônia Oriental, Belém, Pará.

\subsection{Sensory Evaluation}

The sensory evaluation of NGY and AJ samples was carried out between 48 and 72 hours after derivative preparation, with UEPA students, teachers and servers. They were untrained, in number of 60, through acceptance test with a nine points' hedonic scale (Dutcosky, 2013), which comprises point 1 (I disliked it a lot) to 9 (I liked it extremely). Also, data were obtained on age, conventional yogurt consumption frequency and purchase attitude of the derivative with açaí jelly.

\section{Results and Discussion}

\subsection{Preliminary Tests}

Greek yogurt samples, that contained 10 and $15 \%$ of the cream, were similar in assigned scores, and because they did not differ, after the Tukey test $(\mathrm{p} \leq 0.05)$, the treatment with $10 \%$ was chosen, because it had less cream to keep the texture more consistent, a predominant characteristic in this dairy derivative (Table 2).

Table 2. Sensory analysis of preliminary tests.

\begin{tabular}{cccccc}
\hline Formulation & Color & Aroma & Flavor & Texture & Global acceptance \\
\hline 0\% C.L. & $7.46^{\mathrm{a}}$ & $7.10^{\mathrm{a}}$ & $7.32^{\mathrm{b}}$ & $7.42^{\mathrm{ab}}$ & $7.32^{\mathrm{b}}$ \\
$5 \%$ C.L. & $7.96^{\mathrm{a}}$ & $7.32^{\mathrm{a}}$ & $7.28^{\mathrm{b}}$ & $8.21^{\mathrm{a}}$ & $7.75^{\mathrm{ab}}$ \\
$10 \%$ C.L. & $8.21^{\mathrm{a}}$ & $7.78^{\mathrm{a}}$ & $8.07^{\mathrm{ab}}$ & $8.21^{\mathrm{a}}$ & $8.21^{\mathrm{a}}$ \\
$15 \%$ C.L. & $8.14^{\mathrm{a}}$ & $7.67^{\mathrm{a}}$ & $8.46^{\mathrm{a}}$ & $8.17^{\mathrm{a}}$ & $8.46^{\mathrm{a}}$ \\
$20 \%$ C.L. & $7.64^{\mathrm{a}}$ & $7.21^{\mathrm{a}}$ & $7.96^{\mathrm{ab}}$ & $7.17^{\mathrm{b}}$ & $7.75^{\mathrm{ab}}$ \\
\hline
\end{tabular}


${ }^{\mathrm{a}, \mathrm{b}}$ Same letters in the same column are not different $(\mathrm{p} \leq 0.05)$

\subsection{Physicochemical Analysis}

Data from physical-chemical analyzes of buffalo milk may be different from those found by other authors, since buffaloes, during the lactation period, are influenced by climatic factors, which interfere in forage production and, consequently, in milk production throughout the year; in addition to breeding system influences, such as type of food, pasture or feed, breed, age and management (Simões et al., 2014). Buffalo milk physical-chemical analyzes, followed by standard values indicated in the current legislation are in Table 3.

Table 3. Buffalo milk physical-chemical analysis

\begin{tabular}{lcc}
\hline Variable* & Buffalo milk & Legislation** \\
\hline $\mathrm{pH}$ & $6.09 \pm 0.0$ & - \\
Lactic acid acidity (\%) & $0.14 \pm 0.0$ & -14 a $0.18 \%$ \\
Soluble solids ( ${ }^{\circ}$ Brix $)$ & $8 \pm 0.0$ & - \\
Total dry extract $(\%)$ & $10.75 \pm 0.18$ & - \\
Moisture $(\%)$ & $89.24 \pm 0.18$ & - \\
Ashes $(\%)$ & $0.84 \pm 0.05$ & 0.6 a $2.9 \%$ \\
Fat $(\%)$ & $0.82 \pm 0.09$ & - \\
Protein $(\%)$ & $3.01 \pm 0.0$ & - \\
Carbohydrate $(\%)$ & $6.09 \pm 0.0$ & - \\
Energy value $(\mathrm{kcal} / 100 \mathrm{~g})$ & 43.78 & - \\
\hline
\end{tabular}

*Results on wet basis. **(Brasil, 2011).

The analysis of soluble buffalo milk solids resulted in $8{ }^{\circ}$ Brix, without parameters in the current legislation. The $\mathrm{pH}$ observed in the milk used to make Greek yogurt is similar to that mentioned in the literature (Figueiredo et al., 2010). Simões et al. (2014) indicate seasonal variations in buffalo milk composition, on Marajó Island, Pará, where the $\mathrm{pH}$ is 6.87 in the rainy season and 6.86 in the drought.

The titratable acidity in lactic acid is within the estimated by decree No. 62, December 29, 2011, from the Ministry of Agriculture, Livestock, and Supply (Brasil, 2011). This value was close to those described by Modesto Junior et al. (2016), 012\%, and Simões et al. (2014), 
0.16 and $0.15 \%$. Buffalo milk moisture content, determined in the present study, exceeds those mentioned in research with milk of this species, 81.99 and $81.91 \%$ (Figueiredo et al., 2010), 83.2\% (Medhammar et al., 2012) and 83.2\% (Modesto Junior et al., 2016), while that of total dry extract is similar to those determined by Macedo et al. (2001) and (Bailone et al., 2017), however, lower to that observed by Simões (2014). The ash content was similar to that from literature (Verruma and Salgado, 1994; Figueiredo et al., 2010; Medhammaret al., 2012; Simões et al. 2014).

Fat percentage is included in Ordinance No. 62 (Brasil, 2011), with a minimum of 0.6 and a maximum of 2.9, being classified as "partially skimmed milk". In search of less caloric derivatives, milk skimming is a process favorable to yogurt production. As for protein content, the average value is lower than the literature (Caldeira et al., 2010; Medhammar et al., 2012; Simões et al., 2014). The carbohydrate index supersedes those reported by Figueiredo et al. (2010) and Medhammar et al. (2012), and the energy value is lower than that reported by Figueiredo et al. (2010). Physical-chemical analyzes results of AJ's NGY, followed by legislation standard values, are shown in Table 4.

Table 4. Physical-chemical analysis of natural Greek yogurt and açaí jelly

\begin{tabular}{lccc}
\hline Variable* & NGY** & AJ*** & Legislation**** \\
\hline $\mathrm{pH}$ & $4.77 \pm 0.07$ & $4.58 \pm 0.00$ & - \\
Lactic acid acidity (\%) & $0.89 \pm 0.0$ & $1.3 \pm 0.0$ & 0.60 e $2.00 \%$ \\
Soluble solids ( ${ }^{\circ}$ Brix $)$ & $24 \pm 0.0$ & $32 \pm 0.0$ & - \\
Total dry extract $(\%)$ & $28.55 \pm 0.19$ & $37.51 \pm 1.04$ & - \\
Moisture $(\%)$ & $71.44 \pm 0.19$ & $62.48 \pm 1.04$ & - \\
Ashes $(\%)$ & $0.91 \pm 0.42$ & $1.05 \pm 0.02$ & min $6 \%$ \\
Fat $(\%)$ & $6.85 \pm 0.06$ & $7.84 \pm 0.30$ & min $2.9 \%$ \\
Protein $(\%)$ & $16.32 \pm 0.0$ & $11 \pm 0.0$ & - \\
Carbohydrate $(\%)$ & $4.48 \pm 0.0$ & $17.63 \pm 0.0$ & - \\
Energy value (kcal / 100g) & 144.85 & 185.08 & \\
\hline
\end{tabular}

* Results on wet basis. ** NGY - Natural Greek yogurt *** AJ - Greek yogurt with açaí jam. $* * * *$ (Brasil, 2007).

Although there are parameters in Brazilian legislation (Brasil, 2007), $\mathrm{pH}$ value is following 
Modesto Junior et al. (2016) and diverges as to soluble solids. However, it is similar to that of Mantovani et al. (2012). The moisture percentage of NGY and AJ approaches those determined by Sampaio et al. (2011), Mantovani et al. (2012), and Modesto Junior et al. (2016). The ash contents in the NGY and AJ are under the literature (Lima et al., 2011; Sampaio et al., 2011; Antunes et al., 2015; Modesto Junior et al., 2016). The difference between mineral content in NGY and AJ is due to minerals in açaí jelly.

NGY and AJ acidity levels are within the limit of 0.6 and $2 \%$ allowed by the legislation for yogurt (Brasil, 2007), and according to Sampaio et al. (2011). This study's protein contents for NGY and AJ are within the Brazilian legislation for fermented milk (Brasil, 2007), with a minimum value of $2.9 \%$. Dry extract percentages differ from those mentioned in the literature (Lima et al., 2011; Mantovani et al., 2012). NGY and AJ fat content in the study meets the minimum standard of 6\% of current legislation (Brazil, 2007), which is lower than the literature (Lima et al., 2011; Mantovani et al., 2012).

The Carbohydrate index in AJ was higher than that found in NGY, due to the addition of açaí jelly. Nestlé Grego Tradicional brand yogurts have 5\% carbohydrate (Nestlé Brasil Ltda, 2020); Traditional Greek Vigor, 5\% (Vigor Alimentos, 2020); Traditional Danio, 4\% (Danone Brasil, 2020); and Chobani Plain, 4\% (Chobani, 2020).

NGY energy value calculation was higher than that determined in yogurts of Nestlé Grego Tradicional brands, $128 \mathrm{kcal}$ (Nestlé Brasil Ltda, 2020); Traditional Greek Batavo, $295 \mathrm{kcal}$ (Batavo, 2020); Traditional Greek Danone, 146 kcal (Danone Brasil, 2020); Chobani Plain, $89.28 \mathrm{kcal}$ (Chobani, 2020); and lower than the Traditional Greek Vigor, $117 \mathrm{kcal}$ (Vigor Alimentos, 2020). In AJ, energy value calculation was higher than that of Vigor Grego Frutas Vermelhas yogurts, $152 \mathrm{kcal}$ (Vigor Alimentos, 2020); Danio Morango with $128 \mathrm{kcal}$ (Danone Brasil, 2020); Nestlé Grego Frutas Vermelhas, 122 kcal (Nestlé Brasil Ltda, 2020); Batavo Grego Morango, $132 \mathrm{kcal}$ (Batavo, 2020) and Chobani Blueberry, with $120 \mathrm{kcal}$ (Chobani, 2020). Table 5 shows açaí jelly Physico-chemical analyzes.

Table 5. Açaí jelly physico-chemical composition

\begin{tabular}{lcc}
\hline Variable* & Açaí jelly & Legislation** \\
\hline $\mathrm{pH}$ & $4.72 \pm 0.02$ & - \\
Lactic acid acidity (\%) & $2.5 \pm 0.0$ & - \\
Soluble solids ( ${ }^{\circ}$ Brix $)$ & $65 \pm 0.0$ & Min. $62 \%$ a $65 \%$ \\
Total dry extract $(\%)$ & $72.81 \pm 0.87$ & - \\
Moisture $(\%)$ & $27.18 \pm 0.87$ & Max. $38 \%$ \\
Ashes $(\%)$ & $0.27 \pm 0.01$ & -
\end{tabular}


Fat $(\%)$

Protein (\%)

Carbohydrate (\%)

Energy value (kcal / 100g)
$2.25 \pm 0.16$

$0 \pm 0.0$

$70.3 \pm 0.0$

301.45

*Results on wet basis. **(Anvisa, 2005).

Without a comparison parameter in RDC No. 272, September 22, 2005 (Anvisa, 2005), a pH higher than that mentioned in the jelly literature was determined, purple açaí jelly (Oliveira et al., 2014) and white açaí (Couto et al., 2007). Total solids' levels are in accordance with the recommended legislation, which establishes values between 62 and $65{ }^{\circ}$ Brix for jellies produced from fruits, and is similar to that found by Neto et al. (2013) and lower than that of Barcia et al. (2010), in his study with jambolão jelly.

Acaí jelly total acidity was higher than that described in studies with white açaí jelly and buriti jelly (Garcia et al., 2017) and lower than that of açaí purple jelly (Couto et al., 2007). According to Torrezan (1998), jelly's total acidity must be between 0.5 and $0.8 \%$. The moisture content is within the maximum limit of $38 \%$ moisture in fruit jellies (Brasil, 1978), with values close to those of Barcia et al. (2010) and Couto et al. (2007). Ash content is similar to that mentioned by Barcia et al. (2010).

Lipid amount in açaí jelly was higher than those found by Couto et al. (2007) and Barcia et al. (2010), and lower than that of Neto et al. (2013). Açaí jelly did not have a significant protein value, different from the literature (Couto et al., 2007; Neto et al., 2013; Oliveira et al., 2014). Carbohydrate content determined in açaí jelly is close to that of Couto et al. (2007), in white açaí jelly, and surpasses that of Oliveira et al. (2014), in umbu-cajá jelly.

\subsection{Microbiological Analysis}

Microbiological analyzes' results to assess hygienic-sanitary conditions of raw and pasteurized milk are shown in Table 6.

Table 6. Microbiological analysis in raw and pasteurized milk

\begin{tabular}{|c|c|c|c|c|}
\hline Analysis & Raw Milk & $\begin{array}{l}\text { Pasteurized } \\
\text { milk }\end{array}$ & $\begin{array}{l}\text { Standard-Pasteurized } \\
\left.\mathrm{N}^{\mathrm{o}} 12\right)\end{array}$ & (RDC \\
\hline Coliforms at $45^{\circ} \mathrm{C}$ & $>1,100 \mathrm{NMP} / \mathrm{g}$ & $<3 \mathrm{NMP} / \mathrm{g}$ & $4 \mathrm{NMP} / \mathrm{g}$ & \\
\hline Salmonela sp. & Absence & Absence & Absence & \\
\hline $\begin{array}{l}\text { Filamentous fungi and } \\
\text { yeasts }\end{array}$ & $\begin{array}{l}1.35 \quad \mathrm{x} \quad 10^{2} \\
\mathrm{UFC} / \mathrm{ml}\end{array}$ & Absence & - & \\
\hline
\end{tabular}


Pasteurized milk microbiological analysis has demonstrated milk heat treatment efficiency, before dairy culture inoculation for fermentation, due to the absence of undesirable microorganisms, as required by current legislation. NGY microbiological analysis' results are shown in Table 7.

Table 7. Microbiological analyzes' results of Natural Greek Yogurt

\begin{tabular}{lll}
\hline Analyze & Natural Greek Yogurt & Legislation (RDC N 12$)$ \\
\hline Coliforms at $45^{\circ} \mathrm{C}$ & $<3 \mathrm{NMP} / \mathrm{g}$ & $10 \mathrm{NMP} / \mathrm{g}$ \\
Salmonella sp. & Absence & - \\
Filamentous fungi and yeasts & $3.37 \times 10^{-1} \mathrm{UFC} / \mathrm{g}$ & - \\
\hline
\end{tabular}

Coliforms' absence at $45^{\circ} \mathrm{C}$ in the NGY confirms milk handling and processing efficiency, pre and post-fermentation, as well as Salmonella sp. absence; while filamentous fungi and yeasts' counting does not compromise product integrity. Acaí jelly microbiological analyzes' results are shown in Table 8.

Table 8. Açaí Jelly microbiological analyzes’ results

\begin{tabular}{lll}
\hline Analyze & Jelly & Legislation (RDC N 12$)$ \\
\hline Coliforms at $45^{\circ} \mathrm{C}$ & $<3 \mathrm{NMP} / \mathrm{g}$ & - \\
Filamentous fungi and yeasts & Absence & $10^{4} \mathrm{UFC} / \mathrm{g}$ \\
\hline
\end{tabular}

Açaí jelly did not present coliform at $45^{\circ} \mathrm{C}$ and neither filamentous fungi and yeasts, due to the high temperature in the elaboration and efficient processing, which favored dairy derivative health.

\subsection{Sensory Evaluation}

Sensory analysis was performed with untrained tasters, where 53\% were female and $47 \%$ male (Table 9). Regarding yogurt consumption frequency, only $10 \%$ of the tasters consumed daily, $51 \%$ once or more times a week, and $37 \%$ once or more times a month. 
Table 9. Sensory analysis' results

\begin{tabular}{lcc}
\hline Attribute & Natural Greek Yogurt & Greek yogurt with açaí jelly \\
\hline Color & $8.28 \pm 0.73^{\mathrm{a}}$ & $8.25 \pm 0.84^{\mathrm{a}}$ \\
Aroma & $7.97 \pm 0.99^{\mathrm{a}}$ & $8.25 \pm 0.93^{\mathrm{b}}$ \\
Flavor & $7.91 \pm 1.26^{\mathrm{a}}$ & $8.51 \pm 0.82^{\mathrm{b}}$ \\
Texture & $8.20 \pm 1.00^{\mathrm{a}}$ & $8.37 \pm 0.76^{\mathrm{a}}$ \\
Global acceptance & $8.19 \pm 0.89^{\mathrm{a}}$ & $8.55 \pm 0.60^{\mathrm{b}}$ \\
\hline
\end{tabular}

${ }^{\mathrm{a}, \mathrm{b}}$ Same letters on the same line are no different $(\mathrm{p} \leq 0.05)$.

A significant difference was noted in the aroma attributes, since the addition of açaí jelly to yogurt changed the odor, modified the flavor of NGY, and consequently increased the assigned average, making it more accepted. NGY is usually more acid/sour than AJ, so there was an acceptance of Greek yogurt added with açaí jam, which had greater global acceptance, due to its sensory characteristics. The scores of the hedonic scale were plotted in percentages on the graphs, to illustrate the distribution between the attributes. The highest score count in the NGY sensory test was 8 (I liked it very much) and 9 (I liked it extremely). The attributes most appreciated by the judges were 'Aroma', with a score 8, of 39\%, and score 9, 35\%; 'Flavor' with a score 9 , of $34 \%$ of the tasters, and a score of 9 , with $38 \%$; 'Texture', $30 \%$ scored 8 and 50\%, scored 9; 'Global Assessment', 47\% score 8 and 40\%, score 9. The NGY presented an acceptability index of 90 , for $11 \%$ of the tasters and, according to Dutcosky, (2013), the minimum acceptability index is $70 \%$. Thus, the derivative elaborated in the present work has excellent acceptability.

AJ had a higher score, 9 (I liked it extremely). The 'Color' attribute received a score of 9 from $45 \%$ of the tasters; 'Flavor', 68\%; 'Texture', 52\%; and 'Global Assessment', 61\%, while the acceptability index was $93.11 \%$ of the tasters. Thus, it can be said that this derivative obtained excellent acceptability, 2\% more than the NGY index. Figure 2 illustrates the buying attitude of the judges assessed in the sensory test, asking 'I Wouldn't Buy It', 'Maybe I Would Buy It', and 'I Would Definitely Buy It's AJ. 


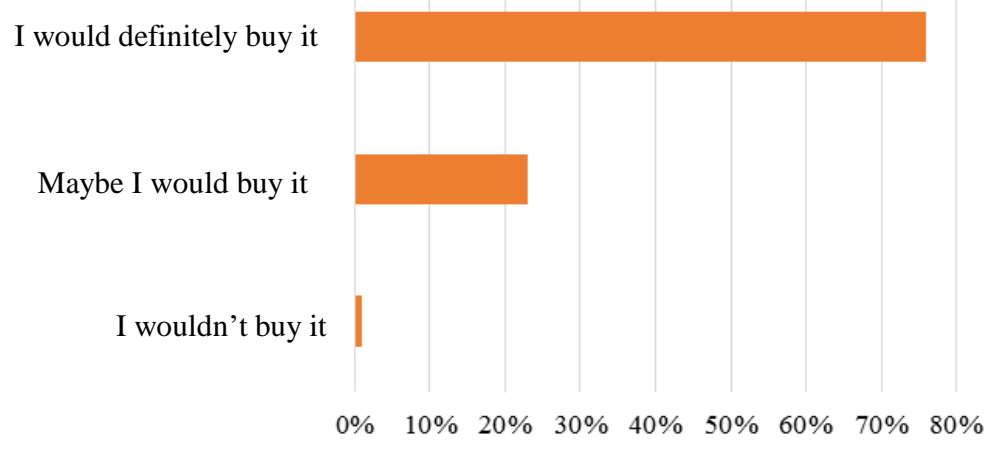

Figure 2. The attitude of buying Greek yogurt with açaí jelly

Among the judges, 76\% said 'I Would Definitely Buy It', being the derivative with characteristics that are attractive to the consumer, a firmer and more consistent texture, the characteristic flavor of buffalo milk, and the taste and color of açaí, which is a highly appreciated fruit.

\subsection{Texture Profile Analysis (TPA)}

The results of the texture profile analysis are shown in Table 10, with a comparison between the NGY and AJ profiles.

Table 10. Texture profile of Greek yogurt made from natural buffalo milk and added with açaí jelly

\begin{tabular}{lll}
\hline Variable & NGY* & AJ** \\
\hline Fracturability (kgf) & 45.49 & 3.11 \\
Hardness (kgf) & 6.44 & 25.01 \\
Cohesiveness & 0.671 & 0.670 \\
Adhesiveness (kgf.mm) & -291.32 & -217.74 \\
Elasticity (mm) & 0.915 & 0.910 \\
Gumminess (kgf) & 4.38 & 17.17 \\
Chewability (kgf.mm) & 4.04 & 15.87 \\
\hline
\end{tabular}

*Natural Greek Yogurt ** Greek Yogurt with Açaí Jelly.

The TPA analysis indicated that the NGY has a high fracturability index, which is the force of the first bite, at the moment of the first compression capable of breaking the food, reflecting 
the low hardness value, which is the force necessary for the food to be deformed between the teeth, tongue or "roof of the mouth" (Bourne, 1978; Steff, 1996; Szczesniak, 1998). Compared to AJ's low fracturability and high hardness, the differences between the samples can be seen due to their proximate compositions (humidity, soluble solids, proteins, among others).

The degrees of hardness of NGY and AJ are higher than those found in research by Ramos et. al. (2009), who measured the hardness in Greek yogurt with cream and without cream; and those by Souza et al. (2011), in five brands of petit Suisse cheese, which can be compared to Greek yogurt, as it has similar physical characteristics, such as using serum separation techniques, with a hardness between 5.42 and $6.65 \mathrm{kgf}$.

Cohesiveness indicates the internal forces to the food that determine the extent of the deformation before breaking in the second compression, and that represents the moment of the bite with the molar teeth (Bourne, 1978; Steff, 1996; Szczesniak, 1998). The results found in the present study, for NGY and AJ, are close to those proposed by Ramos et al. (2009) and Silveira et al. (2016), for the degree of cohesiveness of yogurts; and for Souza et al. (2011); Maruyama et al. (2006) and Shamsia and El-Ghannam (2012), in Greek yogurt made from cow's milk.

Elasticity is the degree of speed in which the food returns to its initial post-compression physical state (Bourne, 1978; Steff, 1996; Szczesniak, 1998). The values found in NGY and AJ, in the present work, are close to those of Maruyama et al. (2006); Ramos et al. (2009); Souza et al. (2011), and Shamsia \& El-Ghannam (2012).

The adhesiveness of NGY and AJ observed in this work, implies that it is not necessary to apply a lot of force, with the tongue, for example, to overcome the attractive forces between the yogurt and other surfaces, such as teeth and "roof of the mouth" (Bourne, 1978; Steff, 1996; Szczesniak, 1998), which means that AJ and NGY cannot be considered sticky and gummy (Szczesniak, 1998).

Gumminess is the density that allows food to be chewed before being swallowed (Bourne, 1978; Steff, 1996; Szczesniak, 1998). This variable was analyzed in NGY and AJ. Thus, the gumminess was higher than that measured by Ramos et al. (2009), while AJ was characterized as pastier, and due to its greater hardness, this fact could also be due to the degree of cohesiveness, but the values are similar in the two samples.

Chewability is the force exerted to disintegrate food into a suitable state to ingest it. The factors that influence chewability are the hardness, cohesiveness, and elasticity of the food. The evaluation of this variable in the AJ was higher, due to the higher degree of hardness, influenced by the greater addition of soluble solids from the açaí jelly, and lower degrees of cohesiveness and elasticity (Bourne, 1978; Steff, 1996; Szczesniak, 1998), characteristics that favor the consumption of yogurt.

\section{Conclusion}

Greek yogurt made with buffalo milk added with açaí jelly is a great example of the 
valorization of the regional raw material, as it enhances the chemical properties and the advantages of consuming buffalo milk, as well as highlights the particularities of açaí. The derivative obtained excellent acceptability, with high nutritional value, protein caloric value, and outstanding physical-chemical and microbiological quality.

The derivative is indicated for a special program supported by the City Halls and/or Government of Pará state, in locations that produce raw materials, to minimize the lack of nutrients, benefiting the health of students from the municipal and state public schools, in addition to generating income and employment in producing communities, by encouraging milk and açaí production. Thus, Greek yogurt made from buffalo milk with açaí jam meets the caloric needs recommended by the Student Food Program.

\section{Acknowledgments}

To FAPESPA and the DERLACA and QUALILEITE projects, for their financial, material and human resources, Universidade do Estado do Pará (UEPA) and the Brazilian Agricultural Research Corporation (Empresa Brasileira de Pesquisa Agropecuária - Embrapa).

\section{References}

Antunes, A. R., Farinã, L. O., Kottwitz, L. B. M., \& Passotto, J. A. (2015). Desenvolvimento e caracterização química e sensorial de iogurte semidesnatado adicionado de concentrado proteico de soro. Revista do Instituto de Laticínios Cândido Tostes, 70(1), 44-54. https://doi.org/10.14295/2238-6416.v70i1.370

Anvisa - Agência Nacional de Vigilância Sanitária. (2001). Regulamento técnico sobre os padrões microbiológicos para alimentos. RDC No 12, de 2 de janeiro de 2001.

Anvisa - Agência Nacional de Vigilância Sanitária. (2005). Regulamento técnico para produtos de vegetais, produtos de frutas e cogumelos comestíveis. RDC $\mathrm{n}^{\circ} 272$, de 22 de setembro de 2005.

Bailone, R. L., Borra, R. C., Roça, R. O., Aguiar, L., \& Harris, M. (2017). Quality of refrigerate draw milk from buffalo cows (bubalus bubalis bubalis) in diferente farms and seasons in Brazil. Ciência Animal Brasileira, 18(1), 1-12. https://doi.org/10.1590/1089-6891v18e-41815

Barcia, M. T., Medina, A. L., \& Zambiazi, R. C. (2010). Características físico-químicas e sensoriais de geleias de jambolão. Boletim do Centro de Pesquisa de Processamento de Alimentos, 28(1), 25-36. https://doi.org/10.5380/cep.v28i1.17894

Batavo. Iogurte Grego Original. Available at:

http://www.batavo.com.br/produtos/iogurte-grego-tradicional-500g/. Accessed in: Jul 02, 2020.

Bittencourt, R. H. F. P. M., Cortez, M. A. S., Mársico, E. T., Santa Rosa, R. M. S., Dib Taxi, M. A. C., Faturi, C., \& Ermita, P. A. N. (2013). Caracterização de Requeijão Marajoara e Minas Frescal produzidos com leite de búfalas no Estado do Pará, Brasil. Ciência Rural, 43(9), 1687-1692. https://doi.org/10.1590/S0103-84782013005000110 
Bligh, E. G., \& Dyer, W. J. (1959). A rapid method of total lipid extration and purification. Canadian Journal of Biochemistry and Physiology, 34(8), 911-917.

https://doi.org/10.1139/y59-099

Bonomo, L. F., Silva, D. N., Boasquivis, P. F., Paiva, F. A., Guerra, J. F., Martins, T. A., ... Oliveira, R. P. (2014). Açaí (Euterpe oleracea Mart.) modulates oxidative stress resistance in Caenorhabditis elegans by direct and indirect mechanisms. PLoSOne, 9(3), e89933. https://doi.org/10.1371/journal.pone.0089933

Bourne, M.C. (1978). Texture profile analysis. Food Technology, 32, 62-66, 72.

Brasil. (2003). Instrução Normativa $N^{o} 360$, de 23 de dezembro de 2003. Ministério da Agricultura, Pecuária e Abastecimento. Aprova Regulamento Técnico sobre Rotulagem Nutricional de Alimentos Embalados, tornando obrigatória a rotulagem nutricional.

Brasil. (2006). Resolução FNDE/CD No32 de 10/08/2006. Estabelece as normas para a execução do Programa Nacional de Alimentação Escolar - PNAE. Ministério da Educação. Fundo Nacional de Desenvolvimento da Educação.

Brasil. (2007). Instrução Normativa $N^{o}$ 46, de 23 de outubro de 2007. Ministério da Agricultura, Pecuária e Abastecimento. Gabinete do Ministro Gabinete do Ministro. no 205, seção 1, p.4. 24/10/2007.

Brasil. (2011). Instrução $n{ }^{\circ} 62$ de 29 de Dezembro de 2011. Regulamento Técnico de Produção, identidade, qualidade, coleta e transporte de leite. Ministério da Agricultura, Pecuária e Abastecimento. Diário Oficial, Poder Executivo. Brasília, DF, Brasil, Seção 1.

Brasil. Ministério da Saúde. Agência Nacional de Vigilância Sanitária. (1978). Resolução de Diretoria Colegiada $\mathrm{n}^{\mathrm{o}} 12$, de 24 de julho de 1978. Normas Técnicas Relativas a Alimentos e Bebidas. Diário Oficial da República Federativa do Brasil, Brasília, DF, 1978. Seção I, p.1-75

Caldeira, L. A., Ferrão, S. P. B., Fernandes, S. A. A., Magnavita, A. P. A., \& Santos, T. D. R. (2010). Desenvolvimento de bebida láctea sabor morango utilizando diferentes níveis de iogurte e soro lácteo obtidos com leite de búfala. Ciência Rural, 40(101), 2193-2198. https://doi.org/10.1590/S0103-84782010005000176

Chobani. Greek Yogurt. Available at:

https://www.chobani.com/products/fruit-on-the-bottom/cup/blueberry/. Accessed in: Feb. 9, 2020.

Couto, L. S., Baptista, R. C., Costa, C. V. P. N., Mattietto, R. de A., \& Pontes, M. A. N. (2007). Obtenção de geleia de açaí branco (Euterpe oleracea, Mart Var. Branco). Encontro de profissionais da química da Amazônia. Belém, PA: Conselho Regional de Química da $6^{\text {a }}$ Região.

Danone Brasil. Available at:

http://tabelasnutricionais.danone.com.br/?product_id=6,108,109,81/. Accessed in: Feb. 08, 2020 . 


\section{MInstitute Macrothink $_{\text {Int }}$}

Darnet, S., Serra, J. L., Rodrigues, A. M. C., \& Silva L. H. M. (2011). A high-performance liquid chromato graphy method to measure to copherols in assai pulp (Euterpe oleracea). Food Research International, 44(7), 2107-2111.

https://doi.org/10.1016/j.foodres.2010.12.039

Dutcosky, S. D. (2013). Análise sensorial de alimentos. (4th ed.). Curitiba, PR: Champagnat.

Figueiredo, E. L., Lourenço Júnior, J. de B., \& Toro, M. J. U. (2010). Caracterização físico-química e microbiológica do leite de búfala "in natura" produzido no estado do Pará. Revista Brasileira de Tecnologia Agroindustrial, 4(1), 19-28.

https://doi.org/10.3895/S1981-36862010000100003

Garcia, L. G. C., Guimarães, W. F., Rodovalho, E. C., Peres, N. R. A., Becker, F. S., \& Damiani, C. (2017). Geleia de buriti (Mauritia flexuosa): agregação de valor aos frutos do cerrado brasileiro. Brazilian Journal of Food Technology, 20, e2016043.

https://doi.org/10.1590/1981-6723.4316

Gouvea, A. C. M. S., Araujo, M. C. P., Schulz, D. F., Pacheco, S., Godoy, R. L. O., \& Cabral, L. M. C. (2012). Anthocyanins standards (cyanidin-3-O-glucosideo and cyanidin-3-O-rutinoside) isolation from freeze-dried açaí (Euterpe oleracea Mart.) by HPLC. Ciência e Tecnologia de Alimentos, 32(1), 43-46.

https://doi.org/10.1590/S0101-20612012005000001

Instituto Adolfo Lutz. (1985). Normas Analíticas do Instituto Adolfo Lutz: Métodos químicos e físicos para análise de alimentos ( $3^{\text {rd }}$ ed). São Paulo, SP: IMESP.

Lima, C. P., Cunico, M. M., Miyazaki, C. M. S., Miguel, O. G., Côcco, L. C., Yamamoto, C. I., \& Miguel, M. D. (2012). Conteúdo polifenólico e atividade antioxidante dos frutos da palmeira Juçara (Euterpe edulis Martius). Revista Brasileira de Plantas Medicinais, 14(2), 321-326. https://doi.org/10.1590/S1516-05722012000200011

Lima, S. C. G., Oliveira, P. D., Lourenço Júnior, J. B., Rodrigues, L. S., \& Neres, L. S. (2011). Efeito da adição de diferentes sólidos na textura, sinérese e característica sensorial de iogurte firme. Revista do Instituto de Laticínios Cândido Tostes, 66(383), 32-39.

Macedo, M. P., Wechsler, F. S., Ramos, A. A., Amaral, J. B., Souza, J. C., Resende, F. D., \& Oliveira, J. V. (2001). Composição físico-química e produção do leite de búfalas da Raça Mediterrâneo no Oeste do estado de São Paulo. Revista Brasileira de Zootecnia, 30(3), 1.084-1.088. https://doi.org/10.1590/S1516-35982001000400024

Mantovani, D., Corazza, M. L., Cardozo Filho, L., \& Costa; S. C. (2012). Elaboração de iogurte com diferentes concentrações de sólidos totais, análise físico- química e perfil da textura. Revista Brasileira de Tecnologia Agroindustrial, 6(1), 680-687.

https://doi.org/10.3895/S1981-36862012000100007

Maruyama, L. Y., Cardarelli, H. R., Buriti, F. C. A., \& Saad, S. M. I. (2006). Textura instrumental de queijo petit-suisse potencialmente probiótico: influência de diferentes combinações de gomas. Ciência e Tecnologia de Alimentos, 26(2), 386-393. 
https://doi.org/10.1590/S0101-20612006000200022

Medhammar, E., Bettoni, R. W., Stadlmayr, B., Nilsson, E., Charrondine, U. R., \& Burlingame, B. (2012). Composition of milk from minor dairy animals and buffalo breeds: a biodiversity perspective. Journal of Science Agriculture, 92, 445-474.

https://doi.org/10.1002/jsfa.4690

Modesto Junior, E. N., Soares, S. S., Sousa, D. D. F., Armo, J. R., Silva, R. M. V., \& Ribeiro, C. F. A. (2016). Elaboração de iogurte grego de leite de búfala e influência da adição de calda de ginja (eugenia uniflora L.) no teor de ácido ascórbico e antocianinas do produto. Revista do Instituto Laticínios Cândido Tostes, 71(3), 131-143.

https://doi.org/10.14295/2238-6416.v71i3.523

Nestlé Brasil Ltda. Iogurte Nestlé Grego Tradicional. Available at: https://https://www.nestle.com.br/marcas/grego/iogurte-grego-tradicional. Accessed in: Feb. 08, 2020.

Neto, B. A. M., Carvalho, E. A., Pontes, K. V., Barretto, W. S., \& Sacramento, C. K. (2013). Chemical, physico-chemical and sensory characterization of mixed açaí (Euterpe oleracea) andcocoa'shoney (theobroma cacao) jellies. Revista Brasileira de Fruticultura, 35(2), 587-593. https://doi.org/10.1590/S0100-29452013000200030

Oliveira, E. N. A., Santos, D. C., Rocha, A. P. T., \& Gomes, J. P. (2014). Desenvolvimento, caracterização e estabilidade de geleia tradicional de umbu-cajá. Revista Brasileira de Fruticultura, 36(3), 640- 651. https://doi.org/10.1590/0100-2945-366/13

Oliveira, P. R., Costa, C. A., Bem, G. F., Cavalho, L. C., Souza, M. A., Lemos Neto, M., Sousa, P. J. C., Moura, R. S., \& Resende, A. C. (2010). Effects of an extract obtained from fruits of Euterpe oleracea Mart. in the componentes of metabolic syndrome induced in C57BL/6J micefed a high-fat diet. Journal of Cardiovascular Pharmacology, 56(6), 619-626. https://doi.org/10.1097/FJC.0b013e3181f78da4

Ramos, T. M., Gajo, A. A., Pinto, S. M., Abreu, L. R., \& Pinheiro, A. C. (2009). Perfil de textura de labneh (iogurte grego). Revista Instituto Laticínios Cândido Tostes, 64(369), 8-12.

Sampaio, A. P. A. M., Lacerda, E. C. Q. L, Junior, W. R. P, Ferrão, S. P. B, Fernandes, S. A. A., \& Dutra, V. S. (2011). Elaboração e caracterização físico-química de iogurte grego sabor cappuccino. Higiene Alimentar, 25(1), 345-347.

Senel, E., Atamer, M., Gürsoy, A., \& Öztekin, F. S. (2011). Changes in some properties of strained (Süzme) goat's yoghurt during storage. Small Ruminant Research, 99(23), 171-177. https://doi.org/10.1016/j.smallrumres.2011.03.042

Shamsia S. M., \& El-Ghannam, M. S. Manufacture of labneh from cow's milk using ultrafiltration retentate with or without addition of permeate concentrate. Journal of Animal Production Advances, 2(3), 166-173. https://doi.org/10.21608/asejaiqjsae.2012.3140

Silva, N., Junqueira, V. C. A., \& Silveira, N. F. A. (2001). Manual de métodos de análise microbiológica de alimentos (2nd ed.). São Paulo: Varela. 
Silveira, M. P., Rocha, L. O. F., Castro, A. L., Brandão, D. C., Guedes, T. J., \& Fernandes, M. K. O. Avaliação da qualidade de labneh (iogurte grego): estudo com consumidores. (2016). Revista do Instituto de Laticínios Cândido Tostes, 71(2), 65-74.

https://doi.org/10.14295/2238-6416.v71i2.505

Simões, M. G., Portal, R. E., Rabelo, J. G., \& Ferreira, C. L. L. F. (2014). Seasonal variations affect the physicochemical composition of bufallo milk and artesanal cheeses produced in Marajo Island (Pa, Brazil). Advanced Journal ofFood Science and Technology, 6(1), 81-91. https://doi.org/10.19026/ajfst.6.3035

Soares, A. D., Rangel, A. H. N., Novaes, L. P., Lima Júnior, D. M., \& Bezerra, K. C. (2013). Composição do leite de búfala em diferentes ordens de parto. Agropecuária Científica no Semiárido, 9(4), 53-60. https://doi.org/10.30969/acsa.v9i4.416

Souza M. P., Silva T. N., Pedrozo E. Á., \& Souza Filho, T. A. (2011). O Produto florestal não madeirável (PFNM) Amazônico açaí nativo: proposição de uma organização social baseada na lógica de cadeia e rede para potencializar a exploração local. Revista de Administração e Negócios da Amazônia, 3(2), 44-57.

Steff, J. M. (1996). Rheological methods in food process engineering ( $2^{\text {nd }}$ ed.). East Lansing: Freeman Press.

Szczesniak, A. S. (1998). Sensory texture profiling: historical and scientific perspectives. Food Technology, 52(8), 52-57.

Torrezan, R. (1998). Manual para a produção de geleias de frutas em escala industrial. Rio de Janeiro, RJ: EMBRAPA - CTAA.

Van Dender, A. G. F., Trevisan, Jr. N.; Yotsuyanagi, K., \& Anjos, V. D. A. (2005). Variação nos parâmetros obtidos na análise do perfil de textura (TPA) em queijos processados com o tipo de recipiente utilizado para conter a amostra. Revista do Instituto de Laticínios Cândido Tostes, 60(345), 393-397.

Verruma, M. R., \& Salgado, J. M. (1994). Análise química do leite de búfala em comparação ao leite de vaca. Scientia Agricola, 51(1), 131-137.

https://doi.org/10.1590/S0103-90161994000100020

Vigor Alimentos. Iogurte Grego Tradicional. Available at:

https://www.nestle.com.br/marcas/grego/iogurte-grego-tradicional. Accessed in: Feb. 08, 2020.

\section{Copyright Disclaimer}

Copyright for this article is retained by the author(s), with first publication rights granted to the journal.

This is an open-access article distributed under the terms and conditions of the Creative Commons Attribution license (http://creativecommons.org/licenses/by/4.0/). 